\title{
Distribution Pattern of Some Heavy Metals in the Soil of Silghat Region of Assam (India), Influenced by Jute Mill Solid Waste
}

\author{
Pronil Kumar Bora, Sanjib Chetry, Dharmendra Kumar Sharma, and Palash Moni Saikia \\ Soil and Water Quality Surveillance Centre, Department of Chemistry, Darrang College, Dist-Sonitpur, Tezpur 784001, Assam, India \\ Correspondence should be addressed to Palash Moni Saikia; palashms@rediffmail.com
}

Received 15 June 2012; Accepted 16 July 2012

Academic Editor: Vladislav Chrastny

Copyright (C) 2013 Pronil Kumar Bora et al. This is an open access article distributed under the Creative Commons Attribution License, which permits unrestricted use, distribution, and reproduction in any medium, provided the original work is properly cited.

\begin{abstract}
Physico-chemical Analysis of the soil of Silghat region of Nagoan district of Assam, India was carried out to assess the possible effect of jute mill solid waste in the distribution pattern of some heavy metals. Soil samples were collected from ten different locations of the dumping site of the mill and their physico-chemical parameters were analyzed. Scanning Electron MicroscopyEnergy Dispersive X-ray analysis (SEM-EDX) and Inductively coupled Plasma-Optical Emission Spectrometer (ICP-OES) analysis of the samples shows that soil of the dumping sites is highly enriched with heavy metals. The concentration of $\mathrm{Fe}, \mathrm{Cu}, \mathrm{Zn}$ and $\mathrm{Pb}$ in the contaminated soil was found to be very much higher than both the continental crust and world rock average values. Correlation studies indicate strong positive correlation between organic carbon content $\left(C_{\text {org }}\right)$ with all the metals investigated. $\mathrm{pH}$ has negative correlation while positive correlation was observed for electrical conductivity with all the metals. Extent of metal contamination was assessed by determining contamination degree (CD) and pollution load index (PLI).
\end{abstract}

\section{Introduction}

The Assam Co-operative Jute Mills Ltd., situated on the south bank of the river Brahmaputra at Silghat in the Nagaon district of Assam (latitude $26^{\circ} 36^{\prime} 52^{\prime \prime} \mathrm{N}$, longitude $92^{\circ} 56^{\prime}$ $14^{\prime \prime} \mathrm{E}$ ), is one of the two jute mills of India in the cooperative sector. It was commissioned in 1970. At present it proves to be a successful cooperative venture and an ISO 9001:2000 certified company.

The jute industry in India generates around 40,000 $t$ of processing wastes as by product, commonly known as cadies [1]. The major constituent of cadies is unspinnable short jute fibers. Other constituents of this waste are parts of finished product, dyed stuff, batching oil, inorganic dirt, and leftover chemicals [2]. Traditionally cadies were utilized by jute industries along with coal as fuel for boiler to generate steam which was required to run the sizing and calendaring machine. However, with technological advancement and change in processing technology steam boilers are no longer indispensable. Moreover the jute cadies are not efficient fuel due to their low calorific value, thermal efficiency, and bulk density $[1,3]$. Attempts have been made to use jute cadies for making composites, laminated sheets, papers, and adhesive bonded nonwoven fabric [3]. However, most of them failed to make any promising impact due to huge production cost and less efficiency of the products. Hence huge quantity of this fibrous industrial waste is often discarded as refuse in open landfills.

The Assam Co-operative Jute Mills LTD has been dumping the jute cadies by product since its commission in various locations on the bank of river Brahmaputra close to the mill (most of these locations are extensively cultivated with rice and tuber root vegetables). Very often they are burnt to reduce the volume. Though jute fibers are ecofriendly and biodegradable, jute cadies are enriched with various chemicals, oils, and dyes and prove to be a potential threat for soil and water pollution if dumped on open surface or near water bodies [4]. One of the most important pollutants of cadies is phenolic compounds. Such organic compounds are highly persistent and can eventually contaminate both animal and human food chain [5]. To increase the softness and flexibility and improve the spinnability, jute fibres are conventionally softened before the carding stage of spinning operations by an emulsion of petroleum oil (b.p. $270-450^{\circ} \mathrm{C}$ ) 
known as jute batching oil (JBO) along with a chemical emulsifier and water in different proportions (oil : emulsifier: water $=20.0: 1.0: 79.0$ ) for the production of fine yarns $[5,6]$. JBO hydrocarbons consist of $n$-alkanes, isoalkanes (e.g., pristane, phytane), and aromatics. The n-alkanes are degradable by bacterial action and they do not exist in nature. But the pristane, phytane, and so forth, resist bacterial action and accumulate in the nature in an undegradable state. Hence, they are harmful and are also not eco-friendly [7]. The polycyclic aromatic hydrocarbons (PAH) fraction of the JBO is recognized as chemical carcinogen and carries harmful effects [8]. Another serious environmental concern is the use of heavy metal salts and compounds in various stages of industrial production of jute fibres and finished products [6]. These chemicals have easy access to the soil of the waste dumping site. Once these heavy metals are deposited, they are not degraded and persist in the environment for years causing serious environmental pollution $[6,9]$. They can be easily absorbed by the green plants, which are primary producers in the ecosystem. As they move up the food chain from producers to consumers, they endanger public health by bioaccumulation in plant and animal tissues and can cause physiological and neurological disorders [9]. These heavy metals can easily bioaccumulate into the tissues of root crops (tuber) which are widely cultivated in the region which is of great concern $[9,10]$. Arsenic and heavy metal accumulation in rice plants (Orya sativa L.) is viewed as a newly recognized disaster for SouthEast Asia, where rice is a staple food [6]. Heavy metals can also affect the ecosystem by migrating into ground water [8]. Hence the present study was undertaken to analyze the physico-chemical parameters and assess the heavy metal contamination of the soil of the dumping yard of the jute mill.

\section{Material and Method}

2.1. Location of the Study Area. Silghat is a small town in the Nagaon district of Assam, India. The dumping yard of Assam Co-operative Jute Mills LTD. (latitude $26^{\circ} 36^{\prime} 52^{\prime \prime} \mathrm{N}$, longitude $92^{\circ} 56^{\prime} 14^{\prime \prime} \mathrm{E}$ ) is a region of around one square $\mathrm{km}$ on the southern bank of river Brahmaputra. The map of Nagaon district of Assam (India) showing Silghat region is presented in Figure 1. The soil of the area is alluvial plain soil. It is grey to yellowish grey and is unaltered alluviam representing sand, silt, and humus rich bog clay. Mineral weathering and geochemical changes are nominal. They are slightly alkaline to acidic in nature.

2.2. Sample Collection. Soil samples were collected from a depth of $5-10 \mathrm{~cm} .20$ samples were collected from various locations of the dumping site at a distance of around $200 \mathrm{~m}$. The soil samples were collected in September, 2011 and stored in $1 \mathrm{~L}$ air tight plastic containers. They were then air dried, grounded, and sieved through $2 \mathrm{~mm}$ sieve.

2.3. Electrical Conductivity and $p H$ Determination. Electrical conductivity and $\mathrm{pH}$ of aqueous extract of the samples were determined using Weiber $\mu$-processor conductivity meter and Systronics MK VI digital $\mathrm{pH}$ meter. Aqueous extract was prepared by mixing $20 \mathrm{~g}$ of the air dried sample with $100 \mathrm{~cm}^{3}$ of double distilled water in a $200 \mathrm{~cm}^{3}$ beaker. The mixture was stirred for 30 minutes at $40^{\circ} \mathrm{C}$ using a hot plate with magnetic stirrer. The mixture was then allowed to stand for one hour. The partly settled suspension was then used for the $\mathrm{pH}$ and conductivity measurement [9].

2.4. CHN Analysis. $\mathrm{CHN}$ analysis was done using Perkin Elmer $2400 \mathrm{CHN}$ Analyzer. An inductively coupled plasma optical emission spectrophotometer (ICP-OES), model Perkin Elmer Optima 2100DV, was used to determine the heavy metals in the sample solutions. A scanning electron microscope combined with energy dispersive X-ray spectroscopy (SEM-EDX), make JEOL model JSM-6390LV, was used to record the EDX spectra.

2.5. Analysis for $\mathrm{Na}, \mathrm{K}$, and $\mathrm{Ca}$. Concentration of $\mathrm{Na}$ and $\mathrm{K}$ in the soil samples was determined by using Labtronics digital flame photometer. Concentration of $\mathrm{Ca}$ was determined by titration method proposed by Piper [10].

2.6. Elemental Analysis. $\mathrm{CHN}$ analysis was done using Perkin Elmer $2400 \mathrm{CHN}$ Analyser. An inductively coupled plasma optical emission spectrophotometer (ICP-OES), model Perkin Elmer Optima 2100DV, was used to determine the heavy metals in the sample solutions. A scanning electron microscope combined with energy dispersive X-ray spectroscopy (SEM-EDX), make JEOL model JSM-6390LV, was used to record the EDX spectra.

For ICP-OES analysis solutions were prepared by wet digestion with nitric acid and sulfuric acid. $1 \mathrm{gm}$ of the sample was taken in a $300 \mathrm{~mL}$ flat bottomed Kjeldahl digestion flask containing $10 \mathrm{~mL}$ of concentrated $\mathrm{H}_{2} \mathrm{SO}_{4}$ and $10 \mathrm{~mL}$ of concentrated $\mathrm{HNO}_{3}$. The samples were then digested carefully over a hot plate at low heat $\left(\sim 60^{\circ} \mathrm{C}\right)$, avoiding excessive frothing until brown fumes cease to be evolved and much of the water is driven off. The flask is then allowed to cool. The samples were digested further with $10 \mathrm{ml}$ of $\mathrm{HNO}_{3}$ until white fumes of sulphuric acid are produced. The process is repeated until a clear and colourless digest is obtained. The resulting digest was heated by heating at $100^{\circ} \mathrm{C}$ for 3-5 minutes and cooled. The solution is then diluted with water until the concentration of the sample becomes about $1 \mathrm{ppm}$. About $10 \mathrm{~mL}$ of the solution is taken for analysis [10].

The ICP spectrometer is calibrated with three calibration standards and a blank $\left(20 \% \mathrm{HNO}_{3}\right)$ each time it is used to measure the trace elements present in the digested soil samples. The concentrations of the calibration standards used are $0.2 \mathrm{ppm}, 0.4 \mathrm{ppm}$, and $0.5 \mathrm{ppm}$ (for $\mathrm{Cr}, \mathrm{Ni}$, and $\mathrm{Cu}$ ), $50.0 \mathrm{ppm}$, $100.0 \mathrm{ppm}$, and $200.0 \mathrm{ppm}$ (for $\mathrm{Fe}$ ), $1.0 \mathrm{ppm}, 3.0 \mathrm{ppm}$, and $5.0 \mathrm{ppm}$ (for $\mathrm{Zn}$ ), $0.6 \mathrm{ppm}, 1.0 \mathrm{ppm}$, and $2.0 \mathrm{ppm}$ (for $\mathrm{Pb}$ ) and $0.02 \mathrm{ppm}, 1.0 \mathrm{ppm}$, and $0.25 \mathrm{ppm}$ (for Cd). Standard solutions were prepared in pyrex volumetric flask using Millipore deionized water and used within 24 hours. 


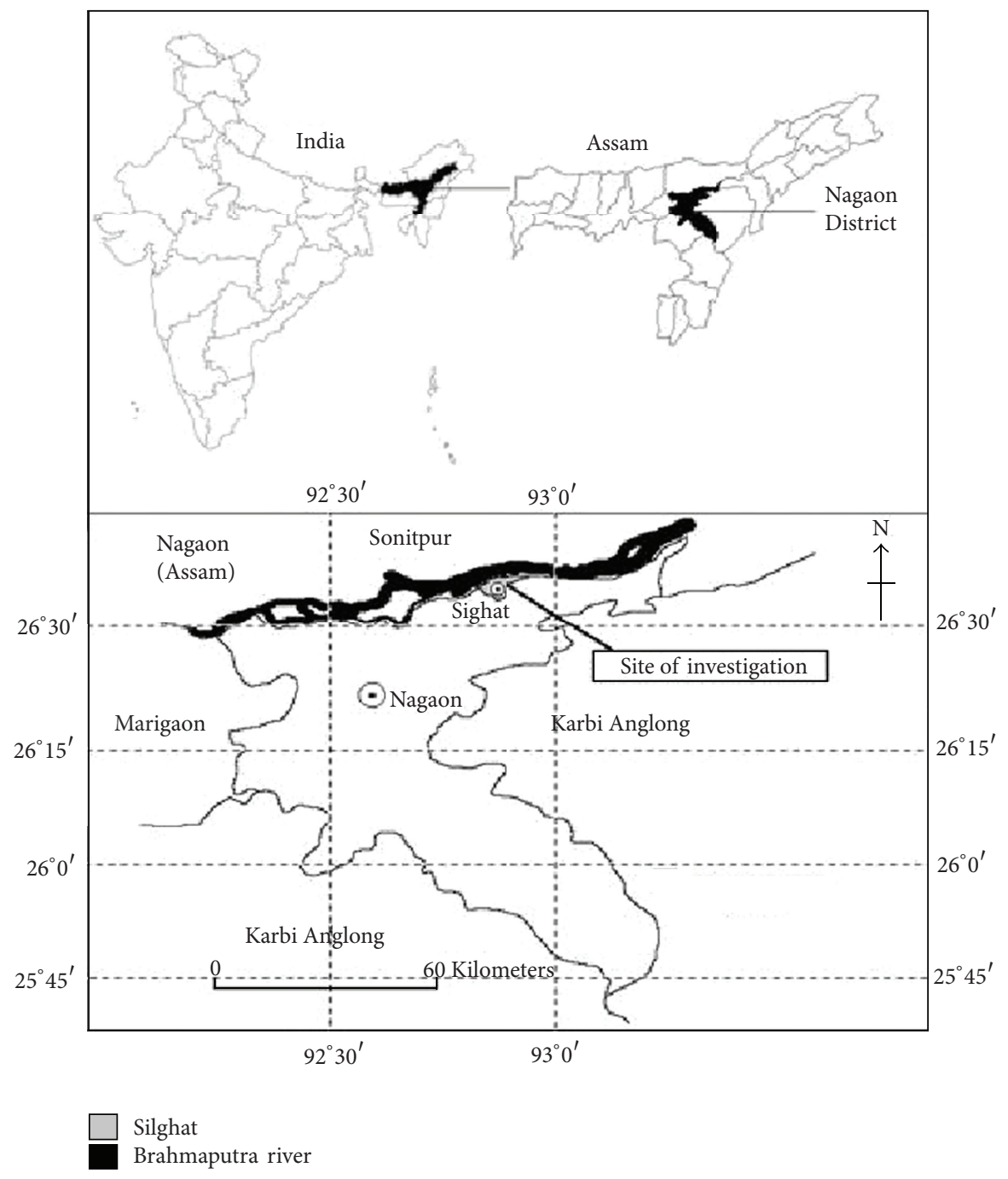

FIGURE 1: Map of Nagaon district of Assam (India) showing the Silghat region.

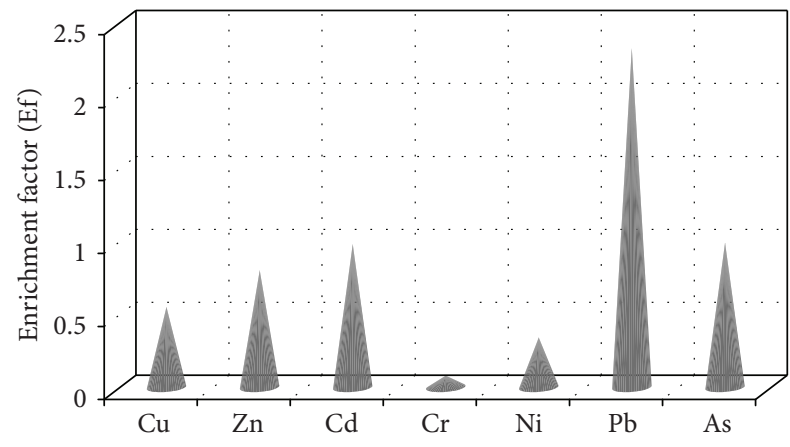

FIGURE 2: Enrichment factors for metals in the soil samples.

\section{Results and Discussion}

The physico-chemical parameters of the analyzed soil samples are shown in Table 1. The soil of the jute mill dumping yard was found to be slightly acidic with an average $\mathrm{pH}$ of
6.20. The acidic nature of the soil favours bioaccumulation and biomagnifications of heavy metals [11]. The electrical conductivity of the $1: 5$ soil suspensions was found to be in the range of 1.02 to $3.02 \mathrm{mS} / \mathrm{cm}$. The high value of electrical conductivity indicates the presence of appreciable amount of ions in the soil samples [12]. Chloride contents of the samples were determined by rapid titration method [10]. Concentrations of sulfate and nitrate in the soil samples were determined according to the method proposed by Ben Mussa et al. [13] and Kolo et al. [14]. The average values of chloride, sulfate, and nitrate in the soil samples were found to be $10.26 \mathrm{mg} / \mathrm{Kg}, 5.80 \mathrm{mg} / \mathrm{Kg}$, and $0.094 \mathrm{mg} / \mathrm{Kg}$ respectively, as shown in Table 2. High concentration of sulfates in the soil indicates anthropogenic influence [15]. The anion holding capacity of the soil increases with decrease in $\mathrm{pH}$ [13]. The random distribution of the anions can be, therefore, attributed to the unequal distribution of soil $\mathrm{pH}$. Organic carbon content of the soil was determined by the Walkley and Black rapid titration method [16]. It was observed that the percentage of organic carbon content of the 
TABLE 1: Physico-chemical parameters of the soil samples.

\begin{tabular}{|c|c|c|c|c|c|c|c|c|c|c|c|}
\hline \multirow{2}{*}{ Sr. No. } & \multirow{2}{*}{ Parameters } & \multicolumn{10}{|c|}{ Soil Samples } \\
\hline & & S1 & S2 & S3 & S4 & S5 & S6 & S7 & S8 & S9 & S10 \\
\hline (1) & $\mathrm{pH}$ & 6.02 & 6.15 & 6.45 & 5.98 & 5.60 & 6.80 & 5.53 & 6.98 & 7.00 & 5.40 \\
\hline (2) & Electrical conductivity $(\mathrm{mS} / \mathrm{cm})$ & 2.12 & 2.08 & 2.02 & 2.34 & 2.45 & 1.98 & 2.56 & 1.67 & 1.02 & 3.02 \\
\hline (3) & Chloride (mg/Kg) & 12.50 & 8.30 & 7.80 & 12.80 & 13.20 & 7.30 & 13.56 & 6.80 & 6.30 & 14.01 \\
\hline (4) & Sulphate (mg/Kg) & 6.56 & 5.34 & 5.01 & 7.02 & 7.12 & 4.23 & 7.34 & 4.01 & 3.84 & 7.50 \\
\hline (5) & Nitrate $(\mathrm{mg} / \mathrm{Kg})$ & 0.09 & 0.06 & 0.04 & 0.12 & 0.16 & 0.04 & 0.18 & 0.03 & 0.02 & 0.20 \\
\hline (6) & $C_{\text {org }}(\%)$ & 4.02 & 3.42 & 3.23 & 4.67 & 4.84 & 3.10 & 4.90 & 3.08 & 3.02 & 5.02 \\
\hline (7) & $\mathrm{C} / \mathrm{N}$ ratio & 20.26 & 21.02 & 22.76 & 18.84 & 18.43 & 25.07 & 18.76 & 26.89 & 29.48 & 19.56 \\
\hline (8) & $\mathrm{Na}(\mathrm{mg} / \mathrm{Kg})$ & 84.56 & 67.34 & 76.34 & 65.34 & 88.78 & 63.67 & 75.45 & 65.45 & 65.43 & 96.45 \\
\hline (9) & $\mathrm{K}(\mathrm{mg} / \mathrm{Kg})$ & 90.23 & 88.76 & 87.65 & 79.05 & 84.35 & 78.34 & 93.23 & 96.43 & 87.65 & 112.45 \\
\hline$(10)$ & $\mathrm{Ca}(\mathrm{mg} / \mathrm{Kg})$ & 295.62 & 256.67 & 234.45 & 223.67 & 298.87 & 213.89 & 254.89 & 234.89 & 225.76 & 302.45 \\
\hline
\end{tabular}

TABLE 2: Statistics of the elements and physicochemical parameters in soil samples $(n=10)$.

\begin{tabular}{lccccccccc}
\hline & $\mathrm{pH}$ & $\mathrm{EC}$ & $\mathrm{C}_{\mathrm{org}}$ & $\mathrm{Cl}^{-}$ & $\mathrm{SO}_{4}{ }^{2-}$ & $\mathrm{NO}_{3}{ }^{-}$ & $\mathrm{Na}$ & $\mathrm{K}$ & \multicolumn{2}{c}{$\mathrm{Ca}^{-}$} \\
\hline Maximum & 7.0 & 3.02 & 5.02 & 14.01 & 7.50 & 0.20 & 96.45 & 112.45 & 302.45 \\
Minimum & 5.4 & 1.02 & 3.02 & 6.30 & 3.84 & 0.02 & 63.67 & 84.35 & 223.67 \\
Mean & 6.20 & 2.12 & 3.93 & 10.32 & 5.80 & 0.09 & 74.88 & 89.81 & 254.12 \\
Median & 6.08 & 2.10 & 3.72 & 10.40 & 5.95 & 0.07 & 71.39 & 88.20 & 244.89 \\
SD & 0.56 & 0.51 & 0.80 & 3.10 & 1.39 & 0.06 & 10.98 & 9.25 & 31.89 \\
\hline
\end{tabular}

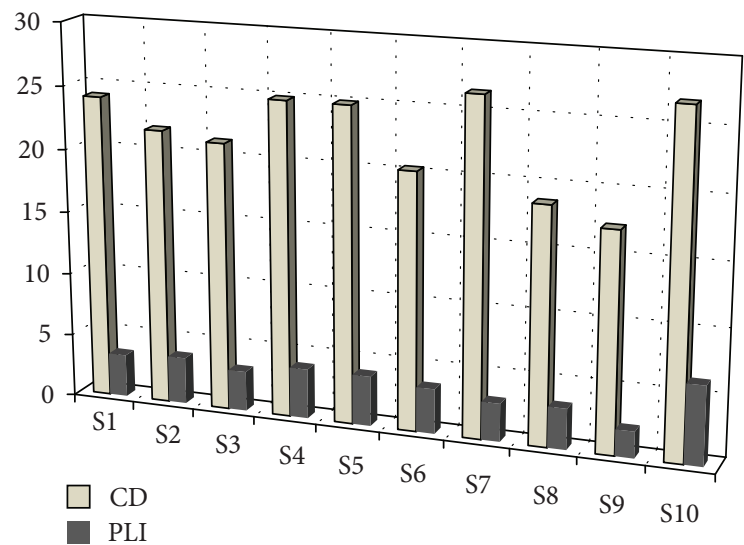

FIGURE 3: Contamination degree (CD) and pollution load index (PLI) of the analyzed soil samples.

soil samples varies from 3.02 to 5.02 . The $\mathrm{C} / \mathrm{N}$ ratio of the samples ranges from 18.43 to 29.48 with an average organic carbon content of $3.93 \%$. The high $\mathrm{C} / \mathrm{N}$ ratio is probably due to the biodegradation of jute fibers and cadies. The soil samples were found to be highly enriched with $\mathrm{Na}$ (average $84.05 \mathrm{mg} / \mathrm{Kg}$ ), $\mathrm{K}$ (average $89.81 \mathrm{mg} / \mathrm{Kg}$ ), and Ca (average $254.12 \mathrm{mg} / \mathrm{Kg}$ ). For proper environmental monitoring and assessment, effective and correct method of data interpreting is necessary [17]. Statistical analysis like correlation studies can be used to effectively identify and assess the sources of contamination $[11,18,19]$.
The linear correlation coefficient $(r)$ often referred to as the Pearson product moment correlation coefficient can be defined as [18]

$$
r=\frac{n \sum x y-\left(\sum x\right)\left(\sum y\right)}{\sqrt{n\left(\sum x^{2}\right)-\left(\sum x\right)^{2}} \sqrt{n\left(\sum y^{2}\right)-\left(\sum y\right)^{2}}}
$$

where $n$ is the number of pairs of data.

The value of is $r$ such that $-1 \leq r \leq+1$. The + and - signs are used for positive linear correlations and negative linear correlations, respectively. If $x$ and $y$ have a strong positive linear correlation, $r$ is close to +1 . An $r$ value of exactly +1 indicates a perfect positive fit. Positive values indicate a relationship between $x$ and $y$ variables such that as values for $x$ increase, values for $y$ also increase. If $x$ and $y$ have a strong negative linear correlation, $r$ is close to -1 . An $r$ value of exactly -1 indicates a perfect negative fit. Negative values indicate a relationship between $x$ and $y$ such that as values for $x$ increase, values for $y$ decrease. If there is no linear correlation or a weak linear correlation, $r$ is close to 0 . A value near zero means that there is a random, nonlinear relationship between the two variables $[11,19,20]$.

Pearson correlation (PC) matrix for the analyzed physicochemical parameters of the soil as influenced by jute mill solid waste is presented in Table 3. From the calculated matrix strong positive correlation of electrical conductivity was observed with chloride content $(r=0.856)$ and organic carbon content $(r=0.841)$ of the soil samples. $\mathrm{pH}$ showed negative correlation with electrical conductivity $(r=-0.899)$.

A strong positive correlation was observed between $\mathrm{Na}$ and $\mathrm{K}(r=0.603)$ and between $\mathrm{Na}$ and $\mathrm{Ca}(r=0.916)$. This may be due to significant geochemical association of $\mathrm{Na}$ with $\mathrm{K}$ and $\mathrm{Ca}[20,21]$. The geochemical association of $\mathrm{Na}-\mathrm{K}-\mathrm{Ca}$ 
TABLE 3: Correlation coefficient of physico-chemical parameters of soil as influenced by jute mill solid waste.

\begin{tabular}{lccccccc}
\hline & E.C. & $\mathrm{pH}$ & $\mathrm{Cl}^{-}$ & $C_{\text {org }}$ & $\mathrm{C} / \mathrm{N}$ & $\mathrm{Na}$ & $\mathrm{K}$ \\
\hline E.C. & 1 & & & & & & \\
$\mathrm{pH}$ & -0.899 & 1 & & & & & \\
$\mathrm{Cl}^{-}$ & 0.856 & -0.944 & 1 & & & & \\
$C_{\text {org }}$ & 0.841 & -0.939 & 0.976 & 1 & & \\
$\mathrm{C} / \mathrm{N}$ & -0.881 & 0.929 & -0.878 & -0.853 & 1 & & \\
$\mathrm{Na}$ & 0.687 & -0.748 & 0.729 & 0.669 & -0.583 & 1 & \\
$\mathrm{~K}$ & 0.402 & -0.358 & 0.328 & 0.308 & -0.098 & 0.603 & 1 \\
$\mathrm{Ca}$ & 0.609 & -0.740 & 0.708 & 0.635 & -0.605 & 0.916 & 0.553 \\
\hline
\end{tabular}

TABLE 4: Heavy metal concentration $(\mathrm{mg} / \mathrm{Kg})$ in soil samples-SEM EDX, ICP-OES data.

\begin{tabular}{|c|c|c|c|c|c|c|c|c|c|c|}
\hline \multirow{2}{*}{ Metal } & \multicolumn{10}{|c|}{ Soil samples } \\
\hline & S1 & S2 & S3 & S4 & S5 & S6 & S7 & S8 & S9 & S10 \\
\hline $\mathrm{Fe}$ & 1790.87 & 1645.23 & 1534.11 & 2020.34 & 2106.67 & 1500.12 & 2205.34 & 1467.23 & 1400.11 & 2269.14 \\
\hline $\mathrm{Cu}$ & 84.63 & 80.62 & 79.57 & 85.87 & 86.88 & 76.45 & 88.89 & 70.11 & 68.23 & 89.91 \\
\hline $\mathrm{Zn}$ & 212.09 & 200.11 & 198.23 & 216.09 & 220.09 & 196.11 & 221.67 & 190.11 & 176.22 & 222.12 \\
\hline $\mathrm{Cd}$ & 9.67 & 8.34 & 8.00 & 9.69 & 9.71 & 7.67 & 10.06 & 7.01 & 6.86 & 10.12 \\
\hline $\mathrm{Cr}$ & 9.56 & 8.40 & 7.34 & 9.70 & 9.85 & 6.12 & 9.90 & 5.02 & 9.96 & 10.02 \\
\hline $\mathrm{Ni}$ & 3.45 & 2.12 & 2.01 & 3.57 & 3.65 & 1.98 & 4.02 & 0.96 & 0.43 & 4.10 \\
\hline $\mathrm{Pb}$ & 112.98 & 100.11 & 98.06 & 114.13 & 116.23 & 84.53 & 123.11 & 79.67 & 67.83 & 125.12 \\
\hline As & 23.14 & 19.12 & 16.02 & 24.14 & 25.26 & 15.11 & 25.99 & 14.03 & 13.01 & 26.14 \\
\hline
\end{tabular}

in the soil shows that these metals are deposited from anthropogenic sources, since there is no known geogenic source which can contribute to this type of association in the study area [19].

The soil samples were analyzed for eight different heavy metals. The SEM-EDX and ICP-OES data for the heavy metal concentration is shown in Table 4. The concentration of heavy metals in the soil samples was found in the order $\mathrm{Cr}<\mathrm{Cd}$ $<\mathrm{As}<\mathrm{Cu}<\mathrm{Pb}<\mathrm{Zn}<\mathrm{Fe}$. The average values of the metal concentration are $\mathrm{Fe}(1793.90 \mathrm{mg} / \mathrm{Kg}), \mathrm{Cu}(81.12 \mathrm{mg} / \mathrm{Kg})$, $\mathrm{Zn}(205.28 \mathrm{mg} / \mathrm{Kg})$, Cd $(8.71 \mathrm{mg} / \mathrm{Kg}), \mathrm{Cr}(8.08 \mathrm{mg} / \mathrm{Kg}), \mathrm{Ni}$ (2.63 mg/Kg), Pb (102.17 mg/Kg), and As (20.20 mg/Kg). The concentration of $\mathrm{Fe}, \mathrm{Cu}, \mathrm{Cd}, \mathrm{Zn}$, and $\mathrm{Pb}$ was found to be very much higher than both the continental crust and world surface rock average values as shown in Table 5 [20, 22, 23]. Concentration of $\mathrm{Ni}$ and $\mathrm{Cr}$ was found to be much below that of the two reference values [24, 25]. This clearly indicates the excessive use of chemicals in the industrial stages of the jute mill. It may be noted that there is practically no human activity in the dumping yard of the mill except an annual religious fair that took place in April every year and lasted for about 10-15 days. Use of chemical fertilizers in some part of the abandoned yard for agricultural purpose may be one of the sources of heavy metals like $\mathrm{Zn}$. The average concentration of As in the control soil was found to be $10 \mathrm{mg} / \mathrm{Kg}$ and within the range of $2.0-16.3 \mathrm{mg} / \mathrm{Kg}$ which is quite close to that observed in the investigated region $(20.20 \mathrm{mg} / \mathrm{Kg})$. This indicates that the concentration of As in the investigated region may be attributed to geogenic factor rather than anthropogenic factors. Uncontaminated soils usually contain $1-40 \mathrm{mg} \mathrm{kg}^{-1}$ of arsenic, with lowest concentrations in sandy soils and those derived from granites, and higher concentrations in alluvial and organic soils $[19,26]$. Therefore, the investigated soils can be regarded as uncontaminated by arsenic, as the pseudo-total amount of As was within the range $13.01-26.14 \mathrm{mg} \mathrm{kg}^{-1}$. Among the different oxidation states of As, arsenite As(III) and arsenate $\mathrm{As}(\mathrm{V})$ are the main inorganic forms in most contaminated soils and sediments. In oxygen-rich environments and welldrained soils, As(V) species dominate and under reducing conditions As(III) is the stable oxidation state [26].

Pesticides and fertilizers used in the cultivation of jute crops which serve as the raw material of the mill can be a potent source of these heavy metals. However, the industrial activity of the jute mill can be considered as the principal source of the heavy metal contamination in the region.

Correlation coefficient of physico-chemical parameters of soil with heavy metals in soil as influenced by jute cadies is shown in Table 6. All the heavy metals showed positive correlation with electrical conductivity, chloride content and organic carbon content. These strong positive correlations which are statistically significant indicate an intrinsic relation between them [21-23]. The positive correlation between the heavy metals and chloride content is probably due to the industrial use of metal chlorides in various stages of processing jute yarns and producing the finished products. However negative correlation was observed for all the metals with $\mathrm{pH}$ and $\mathrm{C} / \mathrm{N}$ ratio. Among the metals $\mathrm{Zn}$ showed the highest positive correlation with electrical conductivity $(r=$ 0.939). Pearson coefficient of 0.985 was observed for As with chloride content indicating that levels of As are highly dependent on chloride content $[23,24]$. 
TABLE 5: Statistics of the determined element in soil samples $(n=10)$ and reference value of element concentration in the continental crust and world surface rock average.

\begin{tabular}{|c|c|c|c|c|c|c|c|c|}
\hline & $\mathrm{Fe}$ & $\mathrm{Cu}$ & $\mathrm{Zn}$ & $\mathrm{Cd}$ & $\mathrm{Cr}$ & $\mathrm{Ni}$ & $\mathrm{Pb}$ & As \\
\hline Maximum & 2269.14 & 89.91 & 222.12 & 10.12 & 10.02 & 4.10 & 125.12 & 26.14 \\
\hline Minimum & 1400.11 & 68.23 & 176.22 & 6.86 & 4.96 & 0.43 & 67.83 & 13.01 \\
\hline Mean & 1793.90 & 81.12 & 205.28 & 8.71 & 8.08 & 2.63 & 102.17 & 20.20 \\
\hline Median & 1718.05 & 82.62 & 205.28 & 8.71 & 8.40 & 2.63 & 102.17 & 20.20 \\
\hline $\mathrm{SD}$ & 302.26 & 7.58 & 14.05 & 1.15 & 1.87 & 1.18 & 17.68 & 4.79 \\
\hline \multicolumn{9}{|l|}{ Reference value } \\
\hline (i) continental crust & - & 25.0 & 65.0 & 0.2 & 126.0 & 76.0 & 15.0 & - \\
\hline (ii) World surface rock average & 3.59 & 32.0 & 129.0 & - & 97.0 & 49.0 & 20.0 & - \\
\hline
\end{tabular}

TABLE 6: Correlation coefficient of physico-chemical parameters of soil with heavy metals in soil as influenced by jute mill solid waste.

\begin{tabular}{lcccccccc}
\hline & $\mathrm{Fe}$ & $\mathrm{Cu}$ & $\mathrm{Zn}$ & $\mathrm{Cd}$ & $\mathrm{Pb}$ & $\mathrm{Cr}$ & $\mathrm{Ni}$ \\
\hline E.C. & 0.885 & 0.933 & 0.939 & 0.877 & 0.929 & 0.860 & 0.919 & 0.868 \\
$\mathrm{pH}$ & -0.956 & -0.968 & -0.948 & -0.962 & -0.971 & -0.964 & -0.948 \\
$\mathrm{Cl}^{-}$ & 0.967 & 0.934 & 0.953 & 0.981 & 0.947 & 0.935 & 0.965 \\
O.C. & 0.992 & 0.905 & 0.933 & 0.945 & 0.915 & 0.899 & 0.930 & 0.985 \\
$\mathrm{C} / \mathrm{N}$ & -0.859 & -0.967 & -0.955 & -0.942 & -0.965 & -0.975 & -0.944 & -0.971 \\
\hline
\end{tabular}

3.1. Enrichment Factor (Ef). The Enrichment factor is convenient tool to assess the degree of heavy metal concentration in soil and sediments. It can be expressed as [22, 24]

$$
\mathrm{Ef}=\frac{\left[\left(C_{x} / \mathrm{Fe}\right)_{\text {sample }}\right]}{\left[\left(C_{x} / \mathrm{Fe}\right)_{\text {background }}\right]},
$$

where $C_{x}$ is the concentration of metal " $x$ " $(\mathrm{mg} / \mathrm{Kg})$ in the contaminated soil. The background value is that of the world surface rock average as shown in Table 4 . Fe was taken as a normalizing element because of its geochemical abundance in the investigated region and since redox sensitive hydroxides and oxides of iron have a controlling influence on heavy metal distribution.

The Ef for metals in the soil of Silghat jute mill dumping site is shown in Figure 2. It has been observed that there is a significant difference in Ef values among metals. When Ef value exceeds 1.0, it indicates higher availability and distribution of metals in contaminated soil, thereby, increasing the metal accumulation in plant species grown on the contaminated soil [23]. It has been observed that the Ef for $\mathrm{Pb}$ (2.32) exceeds the limiting value of 1.0 as shown in Figure 3. The Ef for As (0.99) and Cd (0.98) is almost unity. Ef value of the metals in the soil samples increases in the order, $\mathrm{Cr}<$ $\mathrm{Ni}<\mathrm{Cu}<\mathrm{Zn}<\mathrm{Cd}<\mathrm{As}<\mathrm{Pb}$.

3.2. Contamination Degree (CD). The assessment of overall contamination of the soil was attempted based on the degree of contamination (CD). The sum of the contamination factors (Cf) of all elements examined represents the contamination degree (CD) of the environment [19]. Contamination factor (Cf) $=C_{s} / C_{b}$, where $C_{s}$ is the concentration of the metal in the soil samples and $C_{b}$ is the background value for the metal taken from average shale (here world surface rock average was used). " $m$ " represents multiple metals, that is, all the metals analyzed in this study. The calculated CD values are shown in Figure 3. It was observed that the CD for all the ten soil samples are quite high and within the range of 17-26 which falls in the scale $14 \leq \mathrm{CD} 28$ indicating considerable degree of contamination. CD value was observed to be highest for S10 and minimum for S9.

3.3. Pollution Load Index (PLI). Pollution load index (PLI) for a particular sampling site has been evaluated following the method proposed by Tomlinson et al. [25]. The PLI represents the number of times by which the metal concentration in the soil exceeds the average natural background concentration and gives a summative indication of the overall level of heavy metal toxicity in a particular sample. [When the PLI values exceed 1.0, the soil can be contaminated by anthropogenic inputs and recommends continuous environmental monitoring of the area]. The calculated PLI values of the ten samples are presented in Figure 3. It was observed that the PLI value of the samples ranges from 2.10 to 6.26 against the limiting value of 1.0 indicating comprehensive metal contamination of the soil in the dumping yard of the jute mill.

\section{Conclusion}

The results of the present investigation clearly indicate the adverse effect of jute cadies and waste generated from Assam Co-operative Jute Mills LTD of Silghat on the soil quality of the region. The physico-chemical analysis indicates that the soils has the potential to accumulate heavy metal load which have a tendency to biomagnify and induce long-term adverse environmental impact. The soil of the region is highly contaminated with heavy metal which is possibly due to the long-term deposit of the solid waste generated in the local jute mill. The present study indicates that the untreated jute mill solid waste has adversely affected the soil quality of the region 
and necessitates periodic monitoring and assessment of the soil and plants of the region.

\section{Acknowledgments}

The authors are thankful to Bornali Barooah and Biren Gohain for CHN analysis in the Department of Chemical Sciences, Tezpur University, Assam, India.

\section{References}

[1] P. K. Ganguly, S. K. Bhaduri, and A. Day, "Jute caddies-a potential raw material for hand-made paper," Journal of Scientific and Industrial Research, vol. 63, no. 5, pp. 417-419, 2004.

[2] M. S. Jahan, A. Al-Maruf, and M. Quaiyyumb, "Comparative studies of pulping of Jute fiber, Jute cutting and Jute caddis," Bangladesh Journal of Scientific and Industrial Research, vol. 42, no. 4, pp. 425-434, 2007.

[3] N. Soykeabkaew, P. Supaphol, and R. Rujiravanit, "Preparation and characterization of Jute-and flax-reinforced starch-based composite foams," Carbohydrate Polymers, vol. 58, no. 1, pp. 53-63, 2004.

[4] F. A. Dilruba, M. N. Amin, M. E. Molla, S. M. B. Rahman, and S. Jafrin, "Production of Jute yarns with low content of unsaponifiable matters," Daffodil International University Journal of Science and Technology, vol. 5, no. 1, pp. 10-18, 2010.

[5] F. Ayari, H. Hamdi, N. Jedidi, N. Gharbi, and R. Kossai, "Heavy metal distribution in soil and plant in municipal solid waste compost amended plots," International Journal of Environmental Science and Technology, vol. 7, no. 3, pp. 465-472, 2010.

[6] M. A. Ali, M. M. Rahman, and M. N. Amin, "Waste characterization of industrial processes of bleaching and softening of Jute," Journal of Civil Engineering, the Institute of Engineers, Bangladesh, vol. 25, no. 1, pp. 021-031, 1997.

[7] R. Maheshwari, B. Rani, A. Saxena, M. Prasad, and U. Singh, "Analysis of effluents released from recycled paper industry," Journal of Advanced Scientific Research, vol. 3, no. 1, pp. 82-85, 2012.

[8] W. Wang, Z. Cai, and J. Yu, "Study on the chemical modification process of Jute fiber," Journal of Engineered Fibers and Fabrics, vol. 2, pp. 1-11, 2008.

[9] O. T. Oyelola and A. I. Baatunde, "Effect of municipal solid waste on the levels of heavy metals in Olusosun dumpsite soil, Lagos State, Nigeria," International Journal of Pure and Applied Sciences, vol. 2, no. 1, pp. 17-21, 2008.

[10] C. S. Piper, Soil and Plant Analysis, Interscience, New York, NY, USA, 1966.

[11] V. Parth, N. N. Murthy, and P. R. Saxena, "Assessment of heavy meat contamination in soil around hazardous waste disposal sites in Hyderabad city (India): natural and anthropogenic implications," Journal of Environmental Research and Management, vol. 2, no. 2, pp. 027-034, 2011.

[12] N. Mushtaq and K. S. Khan, "Heavy metal contamination of soils in response to wastewater irrigation in Rawalpindi region," Pakistan Journal of Agricultural Science, vol. 47, no. 3, pp. 215-224, 2010.

[13] S. A. Ben Mussa, H. S. Elferjani, F. A. Haroun, and F. F. Abdelnabi, "Determination of available nitrate, phosphate and sulfate in soil samples," International Journal of PharmTech Research, vol. 1, no. 3, pp. 598-604, 2009.
[14] B. G. Kolo, V. Ogugbuaja, and M. Dauda, "Study on the level of sulphates, phosphates, and nitrates in water and aqueous sediments of Lake Chad Basin Area of Borno State, Nigeria," Continental Journal of Water, Air and Soil Pollution, vol. 1, pp. 13-18, 2010.

[15] H. W. Scherer, G. Welp, and S. Forster, "Sulfur fractions in particle-size separates as influenced by long-term application of mineral and organic fertilizers," Plant, Soil and Environment, vol. 58, no. 5, pp. 242-248, 2012.

[16] L. Rana, R. Dhankhar, and S. Chhikara, "Soil characteristics affected by long term application of sewage wastewater," International Journal of Environmental Research, vol. 4, no. 3, pp. 513-518, 2010.

[17] H. Juahir, S. M. Zain, M. K. Yusoff et al., "Spatial water quality assessment of Langat River Basin (Malaysia) using environmetric techniques," Environmental Monitoring and Assessment, vol. 173, no. 1-4, pp. 625-641, 2011.

[18] P. S. Harikumar and T. S. Jisha, "Distribution pattern of trace metal pollutants in the sediments of an urban wetland in the Southwest coast of India," International Journal of Engineering Science and Technology, vol. 2, no. 5, pp. 840-850, 2010.

[19] S. Srinivasa Gowd, M. Ramakrishna Reddy, and P. K. Govil, "Assessment of heavy metal contamination in soils at Jajmau (Kanpur) and Unnao industrial areas of the Ganga Plain, Uttar Pradesh, India," Journal of Hazardous Materials, vol. 174, no. 1-3, pp. 113-121, 2010.

[20] M. Chakravarty and A. D. Patgiri, "Metal pollution assessment in sediments of the Dikrong River, N.E. India," Journal of Human Ecology, vol. 27, no. 1, pp. 63-67, 2009.

[21] M. Anju and D. K. Banerjee, "Associations of cadmium, zinc, and lead in soils from a lead and zinc mining area as studied by single and sequential extractions," Environmental Monitoring and Assessment, vol. 176, no. 1-4, pp. 67-85, 2011.

[22] B. Dasaram, M. Satyanarayanam, V. Sudarshan, and A. K. Krishna, "Assessment of soil contamination in Patancheru industrial area, Hyderabad, Andhra Pradesh, India," Research Journal of Environmental and Earth Sciences, vol. 3, no. 3, pp. 214-220, 2011.

[23] S. Rai, A. K. Chopra, C. Pathak, D. K. Sharma, R. Sharma, and P. M. Gupta, "Comparative study of physicochemical parameters of soil irrigated with sewage water and canal water of Dehradun city, India," Archives of Applied Science Research, vol. 3, no. 2, pp. 318-325, 2011.

[24] P. U. Singare, R. S. Lokhande, and P. P. Pathak, "Soil pollution along Kalwa Bridge at Thane Creek of Maharastra, India," Journal of Environmental Protection, vol. 1, no. 2, pp. 121-128, 2010.

[25] D. L. Tomlinson, J. G. Wilson, C. R. Harris, and D. W. Jeffrey, "Problems in the assessment of heavy-metal levels in estuaries and the formation of a pollution index," Helgoländer Meeresuntersuchungen, vol. 33, no. 1-4, pp. 566-575, 1980.

[26] T. Karak, O. Abollino, P. Bhattacharyya, K. K. Das, and R. K. Paul, "Fractionation and speciation of arsenic in three tea gardens soil profiles and distribution of As in different parts of tea plant (Camellia sinensis L.)," Chemosphere, vol. 85, no. 6, pp. 948-960, 2011. 

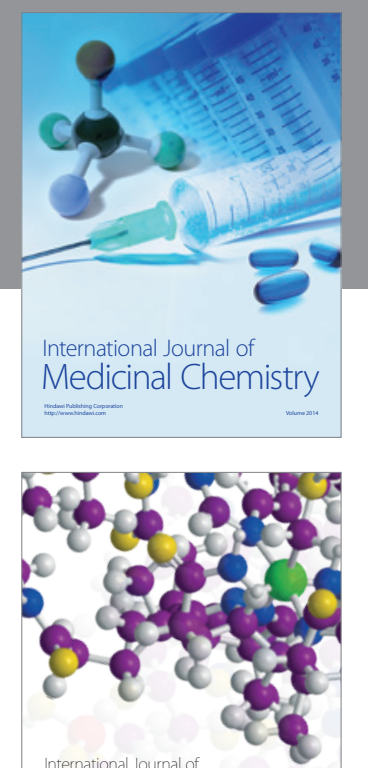

\section{Carbohydrate} Chemistry

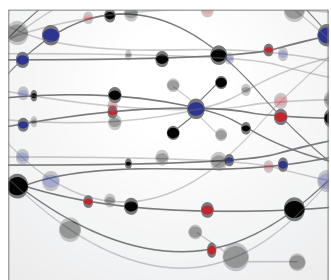

The Scientific World Journal
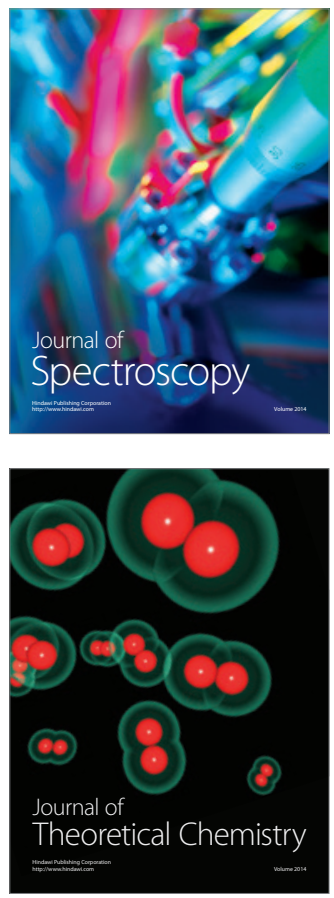
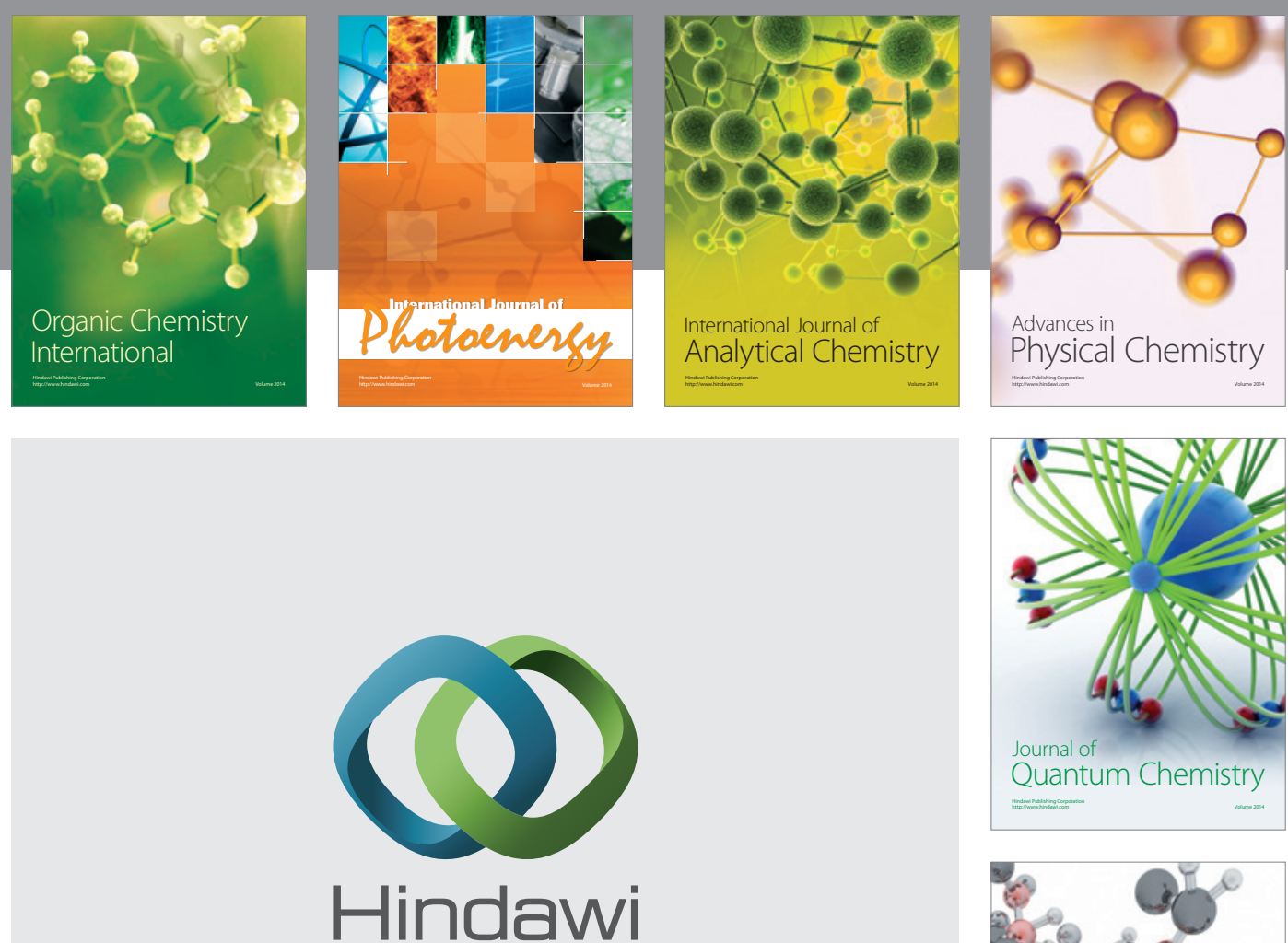

Submit your manuscripts at

http://www.hindawi.com

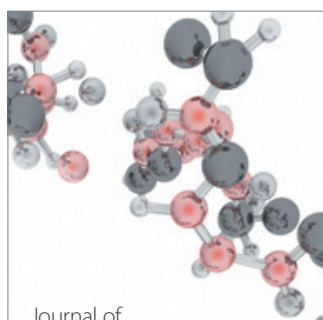

Analytical Methods

in Chemistry

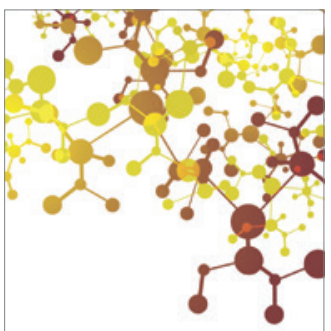

Journal of

Applied Chemistry

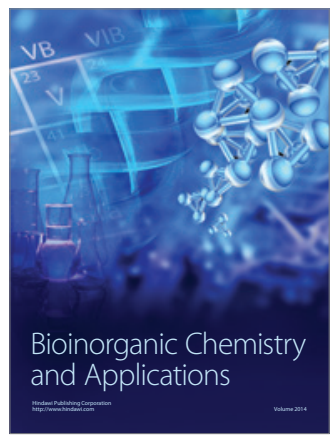

Inorganic Chemistry
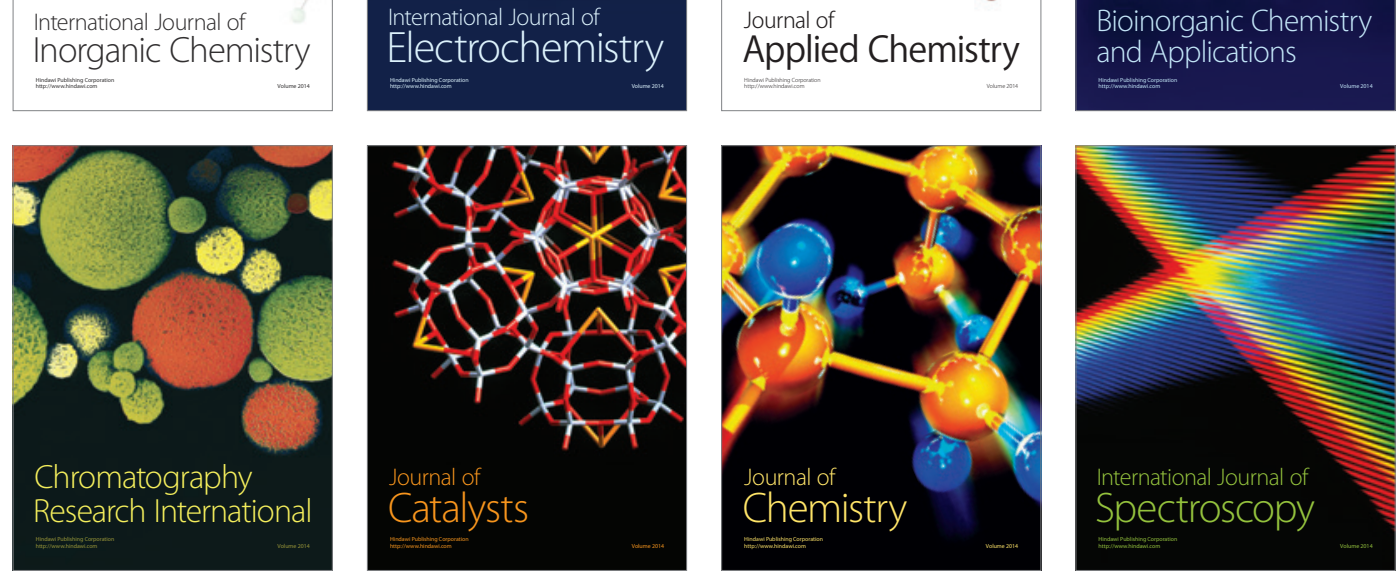